Volume 13, No. 1, Juni 2014

ISSN 1411-514X (print)

ISSN 2355-7737 (online)

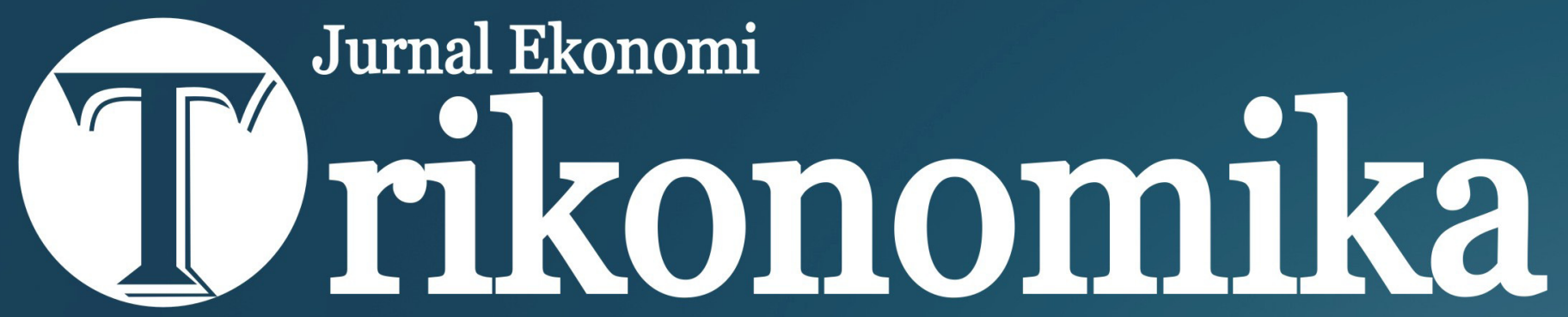




\section{DAFTAR ISI}

Trikonomika, Volume 13, No. 1, Juni 2014

Pengaruh Otonomi dan Akuntabilitas Perguruan Tinggi terhadap Kinerja Manajerial

Isnaeni Nurhayati ...

Keseimbangan Jangka Pendek dan Jangka Panjang Nilai Tukar Rupiah terhadap Dollar Amerika

Horas Djulius, Yudi Nurdiansyah

Kajian Kepemimpinan Transformasional, Komitmen Karyawan, Motivasi, Kepuasan Kerja, dan Kinerja Karyawan

Edy Saptono $21-48$

Pengaruh Kualitas Pelayanan terhadap Kepuasan Mahasiswa Program Ekstensi Fakultas Ekonomi Universitas Jambi

Yenny Yuniarti $49-61$

Determinan Profitabilitas Bank: Suatu Studi pada Bank yang Terdaftar di BEI

Jaja Suteja, Gerinata Ginting $62-77$

Faktor Determinan Minat Wirausaha Mahasiswa Fakultas Ekonomi dan Bisnis Universitas Negeri Gorontalo

Herwin Mopangga $78-90$

Pengaruh Upah dan Pengalaman Kerja terhadap Produktivitas Karyawan Kerajinan Ukiran Kabupaten Subang

Ardika Sulaeman $91-100$

Analisis Harga Saham dan Rata-Rata Abnormal Return Sebelum dan Sesudah Ex-Dividend Date (Studi pada Emiten Indeks Kompas-100)

Alvin Mulya Hidayati $101-107$

Pengaruh Manajemen Laba Akrual dengan Pendekatan Revenue Discretionary Model terhadap Kinerja Perusahaan

Sepriahangga Wahyu Windharta, Nurmala Ahmar $108-118$ 


\title{
Analisis Harga Saham dan Rata-Rata Abnormal Return Sebelum dan Sesudah Ex-Dividend Date (Studi pada Emiten Indeks Kompas-100)
}

\author{
Alvin Mulya Hidayati \\ Fakultas Ekonomi dan Bisnis Universitas Telkom \\ Jl. Telekomunikasi Terusan Buah Batu, Bandung 40257 \\ E-Mail: alvinhidayati234@gmail.com
}

\begin{abstract}
The research is aimed at finding out the stock prices before and after the disclosure of dividend distribution and the difference in abnormal return before and after the disclosure of dividend distribution. The research object is companies consistent in the Index Kompas-100 from February 2009 to January 2014. The type of this research is comparative descriptive. The sample used is 54 issuers obtained by conducting purposive sampling. The research periods are 31 days consisting of 15 days before the disclosure of dividend distribution, 1 day at the disclosure of dividend distribution, and 15 days after the disclosure of dividend distribution. This research uses market adjusted model to obtain the value of expected return. While paired sample t-test is used in hypothesis testing. The result of this research shows that there is no significant difference in stock prices as well as in average abnormal return between 15 days before the disclosure of dividend distribution and 15 days after the disclosure of dividend distribution.
\end{abstract}

Keywords: dividend, ex-dividend date, stock price, abnormal return.

\begin{abstract}
ABSTRAK
Tujuan penelitian ini adalah untuk mengetahui harga saham sebelum dan sesudah pengumuman pembagian dividen, dan apakah terdapat perbedaan abnormal return sebelum dan sesudah pengumuman pembagian dividen. Objek penelitian yang digunakan dalam penelitian ini adalah perusahaan yang secara konsisten berada pada Indeks Kompas-100 periode Februari 2009 sampai Januari 2014. Jenis penelitian yang digunakan dalam penelitian ini adalah deskriptif komparatif. Sampel yang digunakan dalam penelitian ini berjumlah 54 emiten yang diperoleh dengan menggunakan purposive sampling. Periode penelitian yang digunakan, yaitu 31 hari yang terdiri dari 15 hari sebelum pengumuman pembagian dividen, sehari pada saat pengumuman pembagian dividen, dan 15 hari setelah pengumuman pembagian dividen. Penelitian ini menggunakan market adjusted model untuk mendapatkan nilai expected return. Sedangkan untuk pengujian hipotesis, digunakan paired sample t-test. Hasil penelitian penelitian menunjukkan bahwa tidak ada perbedaan yang signifikan terhadap harga saham maupun rata-rata abnormal return antara 15 hari sebelum pengumuman pembagian dividen dan 15 hari sesudah pengumuman pembagian dividen.
\end{abstract}

Kata Kunci: dividen, ex-dividend date, harga saham, abnormal return. 


\section{PENDAHULUAN}

Keberadaan pasar modal di suatu negara bisa menjadi acuan untuk melihat bagaimana dinamisnya bisnis di negara yang bersangkutan dalam menggerakkan berbagai kebijakan ekonominya (Fahmi, 2012). Pasar modal memiliki dua fungsi sekaligus, yaitu pertama, fungsi ekonomi karena pasar modal menyediakan fasilitas untuk mempertemukan dua orang yang berkepentingan, yaitu pihak yang memiliki dana lebih (investor) dan pihak yang memerlukan dana penerbit. Fungsi kedua pasar modal adalah memberikan imbalan (return) bagi investor sesuai dengan investasi yang ditanamkan di suatu perusahaan. Dalam keputusan investasi saham, investor mengharapkan dividen dan hasil dari capital gain.

Dalam pasar modal terdapat berbagai informasi yang didapat dari suatu emitenyang dapat dihubungkan dengan corporate action. Menurut Darmadji dan Fakhruddin (2011), corporate action merupakan aktivitas emiten yang berpengaruh terhadap jumlah saham yang beredar dan berpengaruh terhadap harga saham di pasar. Aktivitas-aktivitas corporate action diantaranya adalah penerbitan right, stock split, saham bonus, dan pembagian dividen. Corporate action memiliki dampak yang signifikan terhadap kepentingan investor karena akan berpengaruh pada jumlah saham yang beredar, kepemilikan saham, serta pengaruhnya terhadap pergerakan harga saham terutama pada saat mendekati ex-dividend date. Exdividend date adalah tanggal di mana perdagangan saham sudah tidak mengandung hak untuk mendapatkan dividen.

Sularso (2003) menyatakan bahwa pada saat $e x$ dividend date investor pada umumnya memprediksi bahwa pembagian dividen akan berdampak pada harga saham. Prediksi tersebut didasari pada pemikiran logis bahwa investor telah kehilangan hak atas return dari dividen. Investor berkeinginan mendapatkan keuntungan cenderung akan memilih untuk tidak dalam posisi beli (long position). Dengan demikian, harga saham tersebut akan mengalami penurunan sebanding dengan nilai return yang telah hilang. Adanya pemikiran tersebut akan mendorong harga atau nilai saham dipasar mengalami penurunan nilai saat dividen diumumkan (Gitman, 2002).
Sularso (2003) menyatakan bahwa pengumuman dividen akan berpengaruh terhadap harga saham di perusahaan, terutama di sekitaran pengumuman dividen saat ex-dividend date. Hasil dari penelitian menunjukkan bahwa pengumuman dividen mempengaruhi return saham sebelum dan sesudah exdividend date. Hal ini selaras dengan hasil penelitian yang dilakukan oleh Siaputra dan Atmadja (2006) dan Sisbintari (2012) menyatakan bahwa terdapat perubahan harga saham sebelum dan sesudah exdividend date yang signifikan. Mayoritas harga saham akan mengalami penurunan pada saat setelah ex-dividend date. Namun, hasil penelitian yang dilakukan oleh Suparno (2013) menyatakan bahwa tidak terdapat perbedaan yang signifikan terhadap harga saham sebelum dan sesudah ex-dividend date. Hal ini menunjukkan bahwa pembayaran dividen tidak begitu penting, karena tidak mempengaruhi kemakmuran para pemegang saham dan menaikkan harga saham perusahaan.

Menurut Campbell dan Beranek (1955) pembagian dividen tunai akan mengakibatkan penurunan harga saham pada saat ex-dividend date. Boyd dan Jagannathan (1994) mengungkapkan tentang adanya hubungan non linier antara persentase perbedaan harga saham dengan dividend yield yang terjadi sebagai akibat adanya biaya-biaya transaksi (transaction costs) yang mempengaruhi penetapan harga saham. Hal yang berbeda diungkapkan oleh Bhardwaj dan Brooks (1999) yang menyatakan, bahwa dalam jangka pendek terdapat perbedaan antara dividend income dan penurunan harga saham pada waktu ex-dividend date. Melihat hasil tersebut paling tidak telah memberikan suatu gambaran tentang adanya pengaruh berbeda-beda yang ditimbulkan oleh kebijakan dividen pada waktu ex-dividend date.

Reaksi harga saham dapat diukur menggunakan abnormal return saham sebagai nilai dari perubahan harga. Abnormal return terjadi di seputar publikasi suatu informasi sebagai respon pasar terhadap informasi yang dipublikasikan direspon dengan cepat oleh investor (Tandelilin, 2010). Pada penelitan yang dilakukan Suparno (2013) hasil abnormal return tidak memperlihatkan perbedaan secara signifikan antara sebelum dan sesudah ex-dividend date. Hal ini menunjukkan bahwa persebaran informasi mengenai pengumuman dividen melalui laporan keuangan 
tahunan tidak tersebar secara merata kepada para investor dalam membuat keputusan investasi. Sedangkan pada penelitian yang dilakukan oleh Aamir dan Shah (2011) menyatakan abnormal return negatif pada tanggal pengumuman dividen, tetapi menjadi berubah positif setelah tanggal pengumuman dividen. Penelitian tersebut sebelumnya juga telah dilakukan oleh Lee (1995), Foster III dan Vickrey (1978), Gordon (1962), dan Lonie, et al. (1996) bahwa pengumuman pembayaran dividen positif terhadap abnormal return. Hal ini menunjukkan bahwa pengumuman kebijakan dividen memberikan reaksi yang berbeda-beda pada setiap perusahaan.

Dengan beberapa deskripsi dan hasil penelitian yang telah disebutkan di atas, penulis menganggap bahwa masih diperlukan dukungan teori peristiwa dan fenomena yang terjadi sebelum dan sesudah pengumuman dividend date (ex-dividend date) ini. Selain itu, penelitian ini juga bertujuan ingin melihat bagaimana peristiwa atau fenomena yang terjadi sebelum dan sesudah pengumuman dividen tanggal (ex-dividend date) dalam kondisi pasar modal di Indonesia. Oleh karena itu, untuk menganalisis sejauh mana acara pengumuman dividen terhadap perubahan atau pergerakan harga saham terutama sebelum dan sesudah pengumuman dividen tanggal (ex-dividend date) pada emiten yang terdaftar dalam Indeks Kompas-100.

Saham-saham yang termasuk dalam Indeks Kompas-100 diperkirakan mewakili sekitar 70-80\% dari total nilai kapitalisasi pasar seluruh saham yang tercatat di BEI, maka dengan demikian investor dapat melihat kecenderungan arah pergerakan Indeks Kompas-100. Terdapat pula Indeks Bisnis27 yang merupakan kerja sama dengan Harian Surat Kabar Bisnis Indonesia. Indeks Bisnis-27 baru saja diluncurkan pada 27 Januari 2009. Indeks Kompas100 sering digunakan untuk penelitian, karena anggota sahamnya lebih banyak dan lebih elastis dalam mengikuti pergerakan IHSG, sedangkan Indeks Bisnis-27 memiliki kelemahan, yaitu pergerakannya rentan karena jumlah anggota sahamnya relatif kecil.

\section{METODE}

\section{Jenis Penelitian}

Jenis penelitian yang digunakan dalam penelitian ini adalah deskriptif komparatif dengan pendekatan studi peristiwa (event study). Penelitian deskriptif dilakukan untuk mengetahui nilai variabel independen, baik satu variabel atau lebih (Sugiyono, 2008). Deskriptif dalam penelitian ini adalah menjelaskan bagaimana pergerakan harga saham sebelum dan sesudah ex-dividend date, sedangkan komparatif adalah untuk mengetahui apakah terjadi perubahan rata-rata abnormal return pada saat sebelum dan sesudah ex-dividend date.

\section{Variabel Operasional}

Variabel operasional yang digunakan dalam penelitian ini adalah rata-rata abnormal return 15 hari sebelum dan 15 hari sesudah tanggal ex-dividend date. Rata-rata abnormal return didefinisikan sebagai rata-rata yang diperoleh dari jumlah keuntungan yang sebenarnya dikurangi dengan jumlah keuntungan yang diharapkan dibagi dengan jumlah sekuritas.

\section{Objek dan Sampel Penelitian}

Objek dari penelitian ini adalah Indeks Kompas100 selama periode Februari 2009 sampai Januari 2014 dan teknik pengambilan sampel yang dilakukan adalah purposive sampling dengan kriteria sebagai berikut: 1) Perusahaan yang secara konsisten masuk ke dalam Indeks Kompas-100 periode Februari 2009 sampai Januari 2014. 2) Perusahaan yang secara konsisten dan terus-menerus mengeluarkan dividen selama periode Februari 2009 sampai Januari 2014. 3) Data tanggal pengumuman dividen selama periode yang diterbitkan di media massa. 4) Adanya kelengkapan data harga saham dan dividend per share yang dibagikan selama periode Februari 2009 sampai Januari 2014 dari perusahaan yang membagikan dividen. 5) Tidak melakukan stock split atau aksi korporasi lainnya selama periode penelitian. Berdasarkan kriteria-kriteria di atas, maka diperoleh perusahaan yang memenuhi kriteria sampling, yaitu sebanyak 8 perusahaan dengan 55 sampel.

\section{Teknik Pengumpulan}

Penelitian ini menggunakan data sekunder. Data yang digunakan dalam penelitian ini meliputi:

1) Data perusahaan yang secara konsisten terdaftar pada Indeks Kompas-100 pada periode Februari 2009 sampai Januari 2014 yang juga secara konsisten mengeluarkan dividen. Data diperoleh dari website PT Bursa Efek Indonesia www.idx.co.id. 2) Data harian 
Indeks Kompas-100 periode Februari 2009 sampai Januari 2014 pada event window. Data diperoleh dari website www.finance.yahoo.com. Data rata-rata abnormal return hingga nilai signifikansi abnormal return diperoleh dari pengolahan data.

\section{Model Penelitian}

Model penelitian yang dilakukan dalam penelitian ini adalah untuk membandingkan harga saham dan rata-rata abnormal return sebelum pengumuman peristiwa dan sesudah pengumuman peristiwa seperti yang terlihat dalam Gambar 1. Metode analisis data yang digunakan dalam menguji hipotesis adalah paired sample t-test.

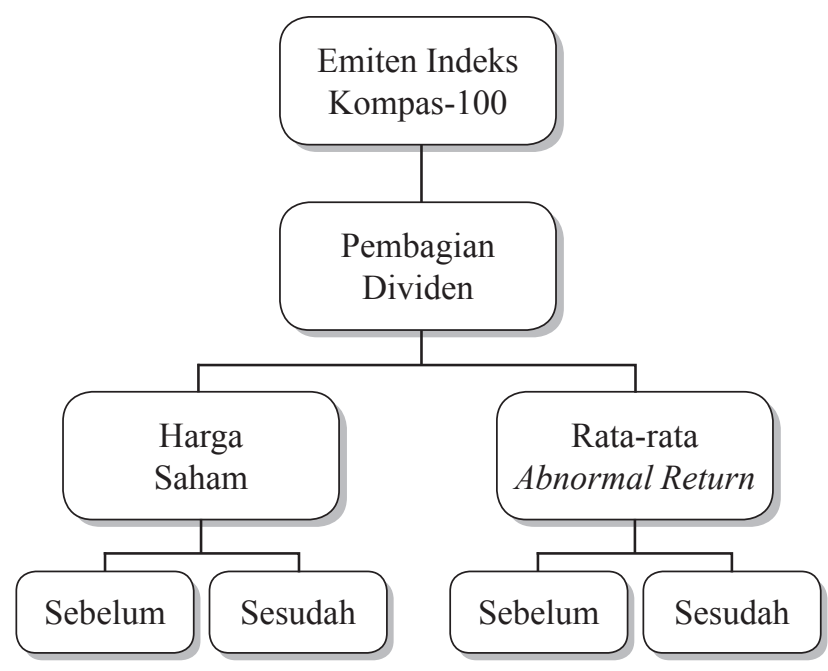

Gambar 1. Model Penelitian

\section{Analisis Data}

Dengan memperhatikan normalitas data melalui serangkaian pengujian Kolmogorov-Smirnov, pengujian hipotesis dilakukan menggunakan metode Paired Sample T-test dengan menggunakan tingkat kepercayaan 95\% $(\alpha=0,05)$. Paired Sample T-test digunakan untuk membandingkan: 1) harga penutupan saham sebelum ex-dividend date dan sesudah exdividend date. 2) Rata-rata abnormal return sebelum ex-dividend date dan sesudah ex-dividend date.

\section{Rancangan Hipotesis Penelitian}

Hipotesis yang akan diajukan dalam penelitian ini adalah:

Hipotesis 1

$\mathrm{H}_{0}=$ Tidak terdapat perbedaan yang signifikan antara harga saham sebelum dan sesudah peristiwa pengumuman pembagian dividen.
$\mathrm{H}_{\mathrm{a}}=$ Terdapat perbedaan yang signifikan antara harga saham sebelum dan sesudah peristiwa pengumuman pembagian dividen.

Hipotesis 2

$\mathrm{H}_{0}=$ Tidak terdapat perbedaan yang signifikan antara rata-rata abnormal return sebelum dan sesudah peristiwa pengumuman pembagian dividen.

$\mathrm{H}_{\mathrm{a}}=$ Terdapat perbedaan yang signifikan antara ratarata abnormal return sebelum dan sesudah peristiwa pengumuman pembagian dividen.

\section{HASIL}

\section{Uji Normalitas Data}

Uji normalitas harga saham adalah sebagai berikut.

Tabel 1. Tests of Normality Harga Saham

\begin{tabular}{llllllll}
\hline & \multicolumn{3}{c}{$\begin{array}{c}\text { Kolmogorov- } \\
\text { Smimov }\end{array}$} & \multicolumn{3}{c}{ Shapiro Wilk } \\
\cline { 2 - 8 } & Statistic & df & Sig. & Statistic & df & Sig. \\
\hline STCKPRICE_SBLM & .118 & 15 & 200 & .970 & 15 & .863 \\
STCKPRICE_SSDH & .123 & 15 & 200 & .969 & 15 & .850 \\
\hline
\end{tabular}

Dari hasil uji normalitas dapat diketahui bahwa data harga saham berdistribusi normal, karena harga saham sebelum ex-dividend date 0,200 >0,05 dan harga saham sesudah ex-dividend date 0,200 >0,05, maka kedua data tersebut dapat menggunakan untuk uji parametrik dengan Paired Sample T-Test, karena asumsi normalitas data terpenuhi.

Uji normalitas rata-rata abnormal return adalah sebagai berikut.

Tabel 2. Tests of Normality Rata-rata Abnormal Return

\begin{tabular}{llllllll}
\hline & \multicolumn{3}{c}{$\begin{array}{c}\text { Kolmogorov- } \\
\text { Smimov }\end{array}$} & \multicolumn{3}{c}{ Shapiro Wilk } \\
\cline { 2 - 8 } & Statistic & df & Sig. & Statistic & df & Sig. \\
\hline STCKPRICE_SBLM & .118 & 15 & 200 & .970 & 15 & .863 \\
STCKPRICE_SSDH & .123 & 15 & 200 & .969 & 15 & .850 \\
\hline
\end{tabular}

Dari hasil uji normalitas dapat diketahui bahwa data average abnormal return berdistribusi normal, karena average abnormal return sebelum exdividend date 0,200 > 0,05 dan average abnormal return sesudah ex-dividend date 0,200 >0,05, maka kedua data tersebut dapat menggunakan untuk uji parametrik dengan Paired Sample T-Test, karena asumsi normalitas data terpenuhi. 
Tabel 3. Paired Sample Test Harga Saham

\begin{tabular}{|c|c|c|c|c|c|c|c|c|}
\hline & \multicolumn{5}{|c|}{ Paired Differences } & \multirow[t]{3}{*}{$\mathbf{t}$} & \multirow[t]{3}{*}{ df } & \multirow[t]{3}{*}{ Sig (2-tailed) } \\
\hline & \multirow[t]{2}{*}{ Mean } & \multirow[t]{2}{*}{ Std. Deviation } & \multirow[t]{2}{*}{$\begin{array}{l}\text { Std. Error } \\
\text { Mean }\end{array}$} & \multicolumn{2}{|c|}{$\begin{array}{c}\text { 95\% Confidence } \\
\text { Interval of the } \\
\text { Difference }\end{array}$} & & & \\
\hline & & & & Lower & Upper & & & \\
\hline & & & & & - & - & & \\
\hline & & & 148.625911 & & 357.61 & .40 & 5 & .690 \\
\hline Pai STCKPRC_SBLM & -59.63636364 & 1102.25926245 & 83 & & 33759 & 1 & 4 & \\
\hline r1 STCKPRC_SSDM & & & & & 5 & & & \\
\hline
\end{tabular}

Tabel 4. Paired Sample Test Harga Saham

\begin{tabular}{|c|c|c|c|c|c|c|c|c|}
\hline & \multicolumn{5}{|c|}{ Paired Differences } & \multirow[t]{3}{*}{$\mathbf{t}$} & \multirow[t]{3}{*}{ df } & \multirow[t]{3}{*}{ Sig (2-tailed) } \\
\hline & \multirow[t]{2}{*}{ Mean } & \multirow[t]{2}{*}{ Std. Deviation } & \multirow[t]{2}{*}{$\begin{array}{l}\text { Std. Error } \\
\text { Mean }\end{array}$} & \multicolumn{2}{|c|}{$\begin{array}{l}95 \% \text { Confidence Interval of } \\
\text { the Difference }\end{array}$} & & & \\
\hline & & & & Lower & Upper & & & \\
\hline Pair AAR_SBLM & .00167201 & .00167201 & .00097821 & -.0028918 & .00363320 & 1.709 & 54 & .093 \\
\hline 1 AAR_SSDH & & & & & & & & \\
\hline
\end{tabular}

\section{Pengujian Hipotesis}

Hasil pengujian hipotesis harga saham ditampilkan pada Tabel 3. Berdasarkan hasil yang diperoleh berdasarkan Tabel 3. adalah mengenai perbedaan rata-rata harga saham antara sebelum dan sesudah peristiwa pengumuman dividen menghasilkan taraf signifikan yang dihasilkan 0,690 >0,05 artinya, tidak terdapat perbedaan yang signifikan antara ratarata harga saham sebelum dan sesudah peristiwa pengumuman dividen. Hal ini menunjukkan bahwa perubahan harga saham disekitaran peristiwa tidak memperlihatkan perubahan yang berarti yang artinya terdapat perubahan namun kecil sekali.

Sedangkan untuk pengujian hipotesis rata-rata abnormal return, data yang dimasukkan adalah data yang lolos uji normalitas. Dengan metode ini akan diketahui apakah terdapat perbedaan yang signifikan pada rata-rata abnormal return yang diteliti selama 15 hari sebelum dan 15 hari sesudah peristiwa pengumuman dividen. Signifikansi rata-rata abnormal return dapat digunakan untuk mengetahui kandungan informasi dari publikasi pembagian dividen. Hasil pengujian terhadap rata-rata abnormal return selama periode peristiwa ditampilkan pada Tabel 4.

Berdasarkan hasil yang diperoleh mengenai perbedaan rata-rata abnormal return antara sebelum dan sesudah peristiwa pengumuman dividen menghasilkan taraf signifikan yang dihasilkan 0,093 $>0,05$, maka dalam pengujian hipotesis ini $\mathrm{H}_{\mathrm{o}}$ diterima yang artinya, tidak terdapat perbedaan yang signifikan antara rata-rata abnormal return sebelum dan sesudah peristiwa pengumuman dividen.

\section{PEMBAHASAN}

\section{Analisis Harga Saham}

Pada saat tanggal ex-dividend investor pada umumnya memprediksi bahwa pembagian dividen akan berdampak pada harga saham. Prediksi tersebut didasari pada pemikiran logis bahwa investor telah kehilangan hak atas return dari dividen. Investor berkeinginan mendapatkan keuntungan cenderung akan memilih untuk tidak dalam posisi beli (long position). Dengan demikian, harga saham tersebut akan mengalami penurunan sebanding dengan nilai return yang telah hilang.

Adanya pemikiran tersebut akan mendorong harga atau nilai saham dipasar mengalami penurunan nilai saat dividen diumumkan. Namun, dari hasil pengujian statistik yang telah dilakukan untuk harga saham terhadap 55 sampel perusahaan yang mengumumkan tanggal ex-dividend yang terdaftar dalam Indeks Kompas-100, hasil yang didapat seperti pada Tabel 3. adalah tidak terdapat perbedaan yang signifikan harga saham antara sebelum dan sesudah peristiwa pengumuman peristiwa tersebut. Hal ini menunjukkan bahwa harga saham terhadap pengumuman dividen menurut pandangan inverstor 
menganut teori irelevansi dividen, yaitu bahwa perubahan nilai dividen tidak memiliki pengaruh terhadap nilai perusahaan, karena nilai perusahaan hanya ditentukan oleh kemampuan dasar untuk menghasilkan laba dan risiko bisnisnya. Dengan kata lain, nilai dari sebuah perusahaan akan tergantung hanya pada laba yang diproduksi oleh aktivaaktivanya, bukan pada bagaimana laba tersebut akan dibagi menjadi dividen dan saldo laba ditahan.

Hasil penelitian ini konsisten dengan hasil penelitian yang dilakukan oleh Suparno (2013) dan Aamir dan Ali Shah (2012) yang menyatakan bahwa tidak ada perbedaan harga saham yang signifikan antara sebelum dan sesudah pengumuman dividen.

\section{Analisis Rata-rata Abnormal Return}

Abnormal return terjadi di seputar publikasi suatu informasi adalah sebagai respon pasar terhadap informasi yang dipublikasikan dan direspon dengan cepat oleh investor. Berdasarkan hasil pengujian statistik yang telah dilakukan untuk rata-rata abnormal return terhadap 55 sampel perusahaan yang mengumumkan tanggal ex-dividend yang terdaftar dalam Indeks Kompas-100, hasil yang didapat seperti pada Tabel 4. adalah tidak terdapat perbedaan yang signifikan rata-rata abnormal return antara sebelum dan sesudah peristiwa pengumuman tersebut. Ini menunjukkan bahwa pengumuman dividen oleh perusahaan melalui laporan keuangan tahunan tidak memiliki kandungan informasi yang relevan bagi pemegang saham untuk mengambil keputusan berinvestasi, misalnya melalui penjualan dan pembelian saham yang diperdagangkan di Bursa Efek Indonesia.

Hasil penelitian ini konsisten dengan hasil penelitian yang dilakukan oleh Suparno (2013) yang menyatakan bahwa tidak ada perbedaan abnormal return yang signifikan antara sebelum dan sesudah peristiwa pengumuman dividen. Hal ini menunjukkan bahwa persebaran informasi mengenai pengumuman dividen melalui laporan keuangan tahunan tidak tersebar secara merata kepada investor dalam membuat keputusan investasi.

\section{KESIMPULAN}

Hasil penelitian ini menunjukkan bahwa pengumuman dividen tidak memiliki perbedaan yang signifikan antara harga saham sebelum dan sesudah ex-dividend date pada Indeks Kompas-100, karena menghasilkan taraf signifikan yang dihasilkan $0,690>0,05$. Maka dalam pengujian hipotesis ini $\mathrm{H}_{0}$ diterima.

Hasil penelitian ini menunjukkan bahwa tidak ada perbedaan yang signifikan antara abnormal return sebelum dan sesudah pengumuman dividen pada Indeks Kompas-100, karena menghasilkan taraf signifikan yang dihasilkan 0,093 >0,05. Maka dalam pengujian hipotesis ini $\mathrm{H}_{0}$ diterima.

Pengumuman kebijakan dividen tidak mengakibatkan yang perubahan signifikan terhadap harga saham karena perubahan nilai dividen tidak memiliki pengaruh terhadap nilai perusahaan. Biasanya nilai perusahaan hanya ditentukan oleh kemampuan dasar untuk menghasilkan laba dan risiko bisnisnya. Oleh karena itu, perusahaan yang terdaftar dalam Indeks Kompas-100 harus meningkatkan laba dari aktiva-aktiva yang dimilikinya.

Pengumuman kebijakan dividen tidak mengakibatkan perubahan yang signifikan terhadap harga saham dan rata-rata abnormal return artinya, pemegang saham lebih tertarik dengan capital gain dibandingkan dengan pembagian dividen, sehingga perusahaan harus meningkatkan kinerja keuangannya.

Pemegang saham perlu mengetahui bahwa pengumuman kebijakan dividen bukan satu-satunya informasi yang memberikan keuntungan pada jumlah saham yang diinvestasikan di perusahaan. Oleh karena itu, pemegang saham harus mampu memfokuskan perhatiannya pada keuntungan yang akan didapatkan dari saham yang diinvestasikan.

Untuk mengembangkan penelitian yang lebih lanjut peneliti menyarankan agar penelitian ini dilakukan dengan meningkatkan jumlah sampel atau memasukan variabel baru. Model penelitian juga perlu diteliti lebih lanjut dengan menggunakan data dan periode yang berbeda agar didapatkan informasi yang mendukung penelitian ini.

\section{DAFTAR PUSTAKA}

Aamir, Muhammad dan Syed Zullfiqar Ali Shah. 2011. Dividend Announcements and The Abnormal Stock Returns for The Event Firm and Its Rivals. Australian Journal of Business and Management Research, 1 (8): 72-76.

Bhardwaj, Ravinder K. dan Brooks, LeRoy D. 1999. Further Evidence on Dividend Yields and the Ex-Dividend Day Stock Price Effect. Journal of Financial Research, 22: 503-514. 
Boyd, John H. dan Jagannathan, Ravi. 1994. ExDividend Price Behavior of Common Stocks. Review of Financial Studies, 7: 711-741.

Campbell, James A. dan William Beranek. 1955. Stock Price Behavior on Ex-Dividend Dates. The Journal of Finance, 10 (4): 425-429.

Darmadji, Tjiptono dan Hendy M. Fakhruddin. 2011. Pasar Modal di Indonesia: Pendekatan Tanya Jawab (edisi ke-3). Jakarta: Salemba Empat.

Fahmi, Irham. 2012. Pasar Modal. Bandung: Alfabeta.

Foster III, Taylor W. dan Don Vickrey. 1978. The Information Content of Stock Dividend Announcement. The Accounting Review, 53 (2): 360-370.

Gitman, Lawrence J. 2002. Principles of Managerial Finance $\left(10^{\text {th }}\right.$ edition). USA: Prentice Hall.

Gordon, Myron J. 1962. The Savings Investment and Valuation of a Corporation. The Review of Economics and Statistics, 44 (1): 37-51.

Lee, Bong-Soo. 1995. The Response of Stock Prices to Permanent and Temporary Shocks to Dividends. The Journal of Financial and Quantitative Analysis, 30 (1): 1-22.

Lonie, A. A., G. Abeyratna, D. M. Power, C. D. Sinclair. 1996. The stock market reaction to dividend announcements: A UK study of complex market signals. Journal of Economic Studies, 23 (1): 32-52.
Siaputra, Lani dan Adwin Surja Atmadja. 2006. Pengaruh Pengumuman Dividen Terhadap Perubahan Harga Saham Sebelum dan Sesudah Ex-Dividend Date di Bursa Efek Jakarta. Jurnal Akuntansi dan Keuangan, 8 (1): 71-77.

Sisbintari, Ika. 2012. Analisis Komparatif Harga Saham Sebelum dan Sesudah Pembagian Dividen: Studi pada Perusahaan-perusahaan Sektor Properti yang Terdaftar di Bursa Efek Indonesia (BEI) Tahun 2010. Inspirat, Inspirasi \& Strategi, 3 (1): 68-79.

Sularso, R. Andi. 2003. Pengaruh Pengumuman Dividen terhadap Perubahan Harga Saham (Return) Sebelum dan Sesudah Ex-Dividend Date di Bursa Efek Jakarta (BEJ). Jurnal Akuntansi \& Keuangan, 5 (1): 1-17.

Suparno. 2013. Dividend Policy Analysis to Manufacturing Company Stock Price Changes Before and After Ex-Dividend Date in Indonesia Stock Exchange (BEI) Period 2008-2012. International Journal of Science and Research, 2 (6): 455-461.

Tandelilin, Eduardus. 2010. Portfolio dan Investasi: Teori dan Aplikasi. Yogyakarta: Kanisius. 